\title{
2 元系相互拡散現象と異相界面反応
}

\section{大西正已* 若松良徳** 下㠃敏唯***}

\section{1. は じめに}

日本金属学会では，1991年に「材料開発に拈ける拡散の 諸問題」についてシンポジウムを開催した。会場では, 構成 物質が熱的に励起されてランダム運動するときにのみフィッ クの法則が成立するといら考方方が質問の形で提出された. 2 年後の1993年には「材料に拉ける拡散(基礎と応用)」をセ ミナーとしてとりあげた。 その際, 相互拡散では濃度勾配よ りもケミカルポテンシャルの勾配を使用した汪うが良いので はないかといら質問があった。これらの質問者はフィックの 法則に対して自己拡散のよらに理想化されたイメージを持 ら, 濃度勾配が拡散の駆動力ではないと考觉ているようであ る.

3 元系相互桩散では, ケミカルポテンシャルの影響により 濃度勾配に逆行するアップヒル拡散の上らに, 明らかなフィ ックの法則からの逸脱現象が諗められる例は別にして, 2 元 系でも濃度勾配が汪とんど存在しないのに, 拡散は速やかに 進行することで, 結果的に相互拡散係数が大きくなるという 認識はあった。ケミカルポテンシャルの影響を調べるため, 同一 2 元系について半無限域の濃度を変えた拡散対を用い て, 相互拡散係数の実験方法条件依存性を調べることがしば しば行われた。相互拡散係数を求めるにはEPMAなどによ り測定された濃度-距離曲線の微分值を必要とし, 微分值に は恣意的誤差が加わることもあって，実験方法依存性がある か否かは明らかでなかった。

このよらな背景から, 筆者らのよらな相互拡散についての

研究者は一定温度一定濃度に括ける相互拡散係数が定数であ ると見なし、ケミカルポテンシャルの勾配が駆動力として物 質の移動に直接関与する場合をも含めて，フィックの法則を 広く解釈してきた。最近に至り，反応拡散あるいは多相拡散 と称される分野では，相接する 2 相間で一方の相が他の相 を食べて成長する場合に，異相界面に拈ける相互拡散係数が 実験条件に依存して異なる可能性が論議され始めた。もし相 互拡散係数が実験条件に依存して変化するならば，フィック の法則としての拡散方程式を拡散実験の解析に使用すること の妥当性を検討しなければならない。

本稿では, 過去に報告された論文の原点に戻り, フィック の法則から基準座標を経て反応拡散までの拡散理論の進歩を たどる。また非平衡から平衡への過渡現象としての相互扗 散, 特に反応拡散に括ける異相界面反応の持つ意味, さらに 異相界面に括ける拡散流束扎上び拡散係数とフィックの法則 との関係について解説する.

\section{2. フィックの法則}

拡散に関する多くの教科書では, 取り扱らものが気体, 液 体あるいは固体に関係なく, 自己拡散と相互拡散を論議する 前にフィックの法則を定義するのが普通であり，その際，第 1 法則が式 $(1)$ ，第 2 法則が式 $(2)$ である.

$$
\begin{aligned}
& J_{i}=-D \frac{\partial C_{i}}{\partial x} \\
& \frac{\partial C_{i}}{\partial t}=\frac{\partial}{\partial x}\left(D \frac{\partial C_{i}}{\partial x}\right)
\end{aligned}
$$

*九州工業大学教授; 工学部物質工学科 ( $\mathbf{7} 804$ 北九州市戸烟区仙水町1-1)

** 九州工業大学助教授; 工学部物質工学科

*** 九州工業大学助教授; 機器分析センター

Binary Interdiffusion Phenomena and Interfacial Reaction; Masami Onishi, Yoshinori Wakamatsu, Toshitada Shimozaki ${ }^{*}$,** Materials Science and Engineering, Faculty of Engineering, Kyushu Institute of Technology, Kitakyushu, ${ }^{* *}$ Center for Instrumental Analysis, Kyushu Institute of Technology, Kitakyushu)

Keywords: binary interdiffusion. Fick's law. reaction diffusion. interfacial reaction. Kirkendall effect. vacancies. phase transformation 1994年 2 月 18 日受理 
ここに $J_{i}$ は拡散流束で, 単位断面積を単位時間内に通過す る物質量であり, $D$ は拡散係数である. $C_{i}$ は単位体積中の 成分 $i$ の物質量, $x$ は距離座標扣よび $t$ は時間である. 式 $(1)$ から式 (2)を誘導するに際し，よく用いられるのが図 1 で あり, 位置 $x$ 飞存在寸る面 I 関する拡散流束 $J_{x}$ と位置 $(x+\Delta x)$ の面 II 関する拡散流束 $J_{(x+\Delta x)}$ との差から, 面 I

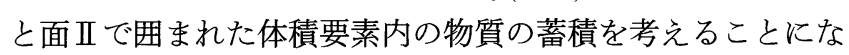
る. 物質の量を表すには, 質量 $(\mathrm{kg})$ あるいは数 (mole 数)の いずれを用いてもよく，物質は必ず質量を持つので，体積要 素内の物質の蓄積は密度变化とみなしてもよい. 図 1 の面 I 捛よび面Iは拡散流束に対する基準面である.

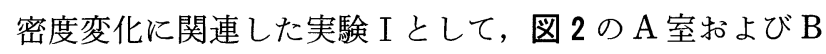
室に同圧力(同じ濃度)の同種の気体を入れる, $\mathrm{A}$ 室の気体 粒子が赤色, B 室の粒子は白と仮定し, 隔壁を取り除けば, $\mathrm{A}$ 室内扣よび $\mathrm{B}$ 室内の何処でも赤ならびに白粒子の存在確 立が同じになるよう均一化に向かって拡散が進行する，濃度 が均一になる前の段階では, 赤の濃度勾配 $\left(\partial C_{R} / \partial X\right)$ お 白の濃度勾配 $\left(\partial C_{W} / \partial X\right)$ が存在し, 次式が成立する.

$$
-\frac{\partial C_{R}}{\partial X}=\frac{\partial C_{W}}{\partial X}
$$

式 (3)の両辺に拡散係数 $D$ を乗じれば, 式 (4) となる.

$$
-D \frac{\partial C_{R}}{\partial X}=D \frac{\partial C_{W}}{\partial X}
$$

拡散が進行中の実験 I で, 始めに存在した隔壁に平行な面を

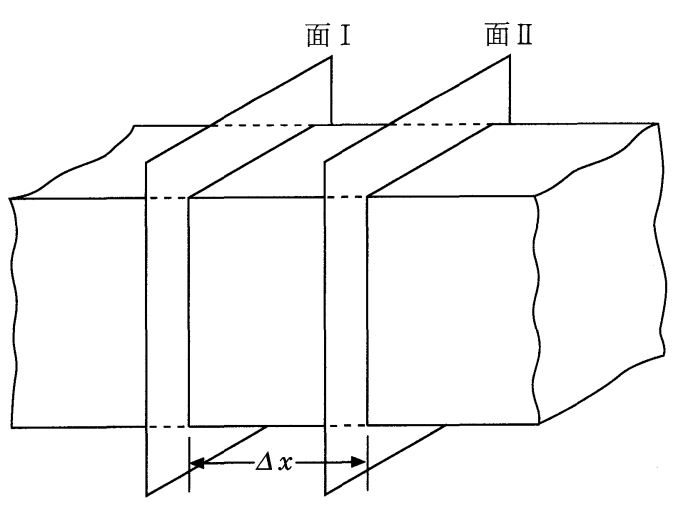

図 1 拡散流束の基準面.

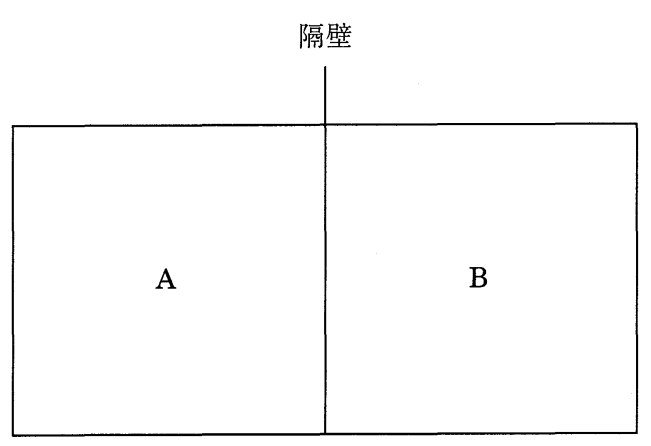

図 2 拡散実験のための容器.
想定し，その面を基準面とする拡散流束 $J_{R}\left(\equiv-D \partial C_{R} / \partial X\right)$ 扣よび $J_{W}\left(\equiv-D \partial C_{W} / \partial X\right)$ の和を求めると零になる。つま $\eta, i=(R, W)$ とすれば, 式 (4)が成立し $\Sigma J_{i}=0$ となり, 任意の数の $R$ 粒子が右方向に移動したとすれば, 同数の $W$ 粒子が左側飞移動しなければならない。もちろん成分 $i$ の流 れに対して, 逆行する同一成分の同一量の流れは打ち消され て, 拡散流束としては計測されない, 実験 I で生じる拡散は 自己拡散であり, $\partial C_{i} / \partial X$ は拡散の駆動力ではない。

取り扱らものが気体, 液体あるいは固体(1)であっても, 物 質の平均自由行程あるいはジャンプ間距離を $\gamma, 1$ 秒間の 3

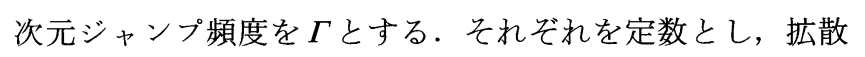
係数 $D=\left(\gamma^{2} \Gamma\right) / 6$ とすることで, フィックの第 1 法則が誘導 される. この場合, 拡散粒子のジャンプの方向はランダムで なければならない、今, かりに, このよらな状態の気体ある いは液体中で拡散が進行しているとして，ぞこか局限された 場所でジャンプ頻度 $\Gamma か ゙$ 変化したとすれば，ジャンプ頻度 の変化はその位置での温度変化をもたらし, 結果として熱対 流が発生する. 熱対流は拡散粒子の一つずつのランダムなジ ャンプではなく，まとまった数の粒子を特定な方向に移動さ せるので，フィックの法則は成立しない。このように考兄て 行くと, 単に熱によって励起された粒子の動きが拡散であ り, 理想ガス内の粒子の移動が〉ィックの法則を導くと考兄 るのも当然のことである.

フィックの第 1 法則についてはオームの法則あるいは熱 伝導を表す式との類似性が論議される。 その一例として, “ $D$, すなわちー $J_{i}$ と $\partial C_{i} / \partial X$ との比が $\partial C_{i} / \partial X$ の大きさにか かわりなく一定である(これはそらである必然性はないが) と いらことが実験的に観測される。この点では式 (1)は抵抗 が電圧降下の大きさによらず一定であるとするオームの法 則, あるいは熱伝導が温度勾配の大きさによらないとする熱 伝導の基本式に似ている”(2). 括弧の中は $D$ が濃度に依存す る変数であってもよいといらことで, 後に触れる俣野法に関 係する. 次に実験 II として, 図 2 で例光ば A 室に気体を, 同種の気体を $\mathrm{A}$ 室より圧力を下げて B 室に入れ, 隔壁を取 り除く. 拡散係数に対応寸るものとして気体の種類に固有の 分散係数とでも称すべきもの, さらに濃度勾配の代わりに圧 力あるいは密度勾配を用いれば, 均一密度になるまでの過程 では式 (1)が成立するはずである.この例, オームの法則 扣上び熱伝導では濃度勾配に相当する項が流束の駆動力とな るに対して、これまでに述べてきたフィックの第 1 法則で は濃度勾配は駆動力ではない,さらに移動するものは, オー ム法則では電流(電子), 熱卮導では熱であり, それら以外に 何も移動しないか，あるいは無視できるに対して，これまで 飞説明してきたフィックの第 1 法則の拡散流束 $J_{i}$ には必ず 逆行する物質の同じ量の拡散流束が存在しなければならな い.つまり $\Sigma J_{i}=0$ の成立である. したがって, 数式上一種 類の成分の密度変化が生じるように示されていても， $\Sigma J_{i}$ $=0$ によて全体としては密度変化は生じてはならない. 当 
然, 図 1 の体積要素内の質量あるいはモル数を一定に維持 する必要があり, このことから後述の基準座標の概念が生ま れた。基準座標には 2 成分の量を固定した座標系と，一方 の成分の量だけを固定した座標系 ${ }^{(3)}$ がある．前者については 後で述べるとして，後者では固定された成分は全く拡散せず (拡散係数が零)，他の成分だけが拡散する．格子間隙に侵入 した原子の拡散を取り扱うに都合のよいのがこの座標系であ り，溶媒固定座標系と称されることもある。この場合には $\Sigma J_{i}=0$ は関係がないので, $\Sigma J_{i}=0$ はフィックの第 1 法則の 成立要因ではない。

固体の金属あるいは合金に限定し，空孔機構による自己拡 散では, 拡散原子と空孔との相関現象(4)さらに追跡子として 放射性同位元素を使用すれば，同位体効果 ${ }^{(5)}$ とより原子の動 きは完全なランダムでないことが知られている。その結果ラ ンダムの場合に比較して拡散係数が変化するが，“はじめに” で述べた質問にもかかわらず，これらの拡散現象をフィック の法則で説明することに問題は無さそらである

\section{3. 相互拡散に対する俣野法の適用と基準座標}

\section{（1）俣野法}

実験而として, 気体 $\mathrm{A}$ を図 2 の A 室に, $\mathrm{A}$ とは種類の異 なる気体 B を B 室にそれぞれ同圧力(密度)で入れ拡散させ たとする。この例がいわゆる相互拡散であるが，気体 A 招 よび B が共に理想気体であれば，実験 I と実験 III とは同じ 意味で区別する必要はない，理想気体でなければ，混合のエ ントロピーを含めて, 系全体の自由エネルギーが変化し, 拡 散に関与する異種の気体粒子間の相関状態に变化が生じる. 恐らくジャンプ頻度も定数ではなく, 相互拡散係数も濃度に 依存する. 自己拡散と扔なじく濃度勾配が駆動力でない場合 の拡散に加えて, 非平衡状態を緩和するためにケミカルポテ ンシャルの勾配が駆動力として作用して，拡散を促進する.

拡散係数が濃度に依存する際に拡散係数を求める方法がボ ルッマン-俣野法(6)いわゆる俣野法であり，ボルッマンの提 案により変数 $\lambda(=x / \sqrt{t})$ を導入することで式 $(2)$ を常微分 方程式とし，これを俣野法で解放する。俣野法に必要な初期 条件は式( 5 )である.

$$
\begin{array}{lll}
C=C_{1}(-\infty) & x<0 & t=0 \\
C=C_{1}(+\infty) & x>0 & t=0
\end{array}
$$

$x=0$ の面は俣野面であり, この面はすべての時間 $t$ 亿扔い て $x= \pm \infty$ そ和ける拡散対の両端から一定の距離に固定され ている.さらに $x= \pm \infty$ に招いて拡散流束 $J_{i}$ が零になる必要 がある. 以上の上らな条件下で, ボルッマン変数 $\lambda$ の導入 の可能性, 例えば $C_{i}$ - $\lambda$ 曲線が 1 本のマスターカーブで描け ることが確認されれば俣野法が適用できる。解放の結果, 拡 散流束 $J_{i}$ は式 $(6$ ) で与兄られる.

$$
J_{i}=-\widetilde{D} \frac{\partial C_{i}}{\partial x}=\frac{1}{2 t} \int_{+\infty}^{C_{i}^{*}} x \mathrm{~d} C_{i}
$$

ここに $\tilde{D}$ は相互拡散係数と称され，2 元系で両成分が拡散 するとすれば, $\tilde{D}$ は両成分に共通な值である.

ボルッマン-俣野法の事実上の提案者, 俣野については簡

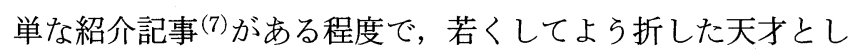
かわからない，俣野法は発表から60年経た今日でも相互拡 散の研究には必ず用いられる有用な方法である.

\section{(2) 基準座標 ${ }^{(8)(9)}$}

\section{(Frame of reference or Coordinate system)}

$C_{i}=N_{i} / V$ の関係を用いて, フィックの第 1 法則 $J_{i}$ を式 (7)のよら飞変形する。ここに $N_{i}$ は成分 $i$ のル分率, $V$ は溶体のモル体積である。

$$
-\widetilde{D} \frac{\partial C_{i}}{\partial x}=-\frac{\widetilde{D}}{V} \frac{\partial N_{i}}{\partial x}-C_{i} V \widetilde{D} \frac{\partial(1 / V)}{\partial x}
$$

成分 1 および 2 そついての部分モル体積を $\bar{V}_{1}$ および $\bar{V}_{2} て ゙$ 表せば, $\bar{V}_{1} \mathrm{~d} C_{1}+\bar{V}_{2} \mathrm{~d} C_{2}=0$ は恒等式であるから, 次式が成 り立つ。

$$
\bar{V}_{1} J_{1}+\bar{V}_{2} J_{2}=0
$$

式 (8)は体積流束の和が零であることを示し, 式 (7)左辺 の拡散流束 $J_{i}$ の基準面を規定するので， $J_{i}$ は体積固定系の拡 散流束之称される. 式 ( 7 ) 右辺第 1 項はモル数固定系の拡 散流束であり，これを $F_{i}$ で表せば $\Sigma F_{i}=0$ でなければなら ない．右辺第 2 項 $C_{i}[V \tilde{D} \partial(1 / V) / \partial x]$ の中括弧の中は速度 $u(\mathrm{~m} / \mathrm{s})$ を意味する．したがって，Vが濃度に依存する変数 であれば， $J_{i}$ の基準面と $F_{i}$ の基準面とは $u$ なる速度で相対 的に移動するＶVが定数であれば式 $(7)$ の右辺第 2 項は零 となり, 拡散流束の $J_{i}$ と $F_{i}$ は等しくなる. 当然のことなが ら $J_{i}$ と $F_{i}$ の基準面も一致し, 式 (8)では $\bar{V}_{1}=\bar{V}_{2}$ の状態に 対応寸る。な扮輸送現象の分野では, 質量固定座標系の拡散 流束 $\left(\mathrm{kg} / \mathrm{m}^{2} \cdot \mathrm{s}\right)$ を使用することもあり，質量基準座標系では 質量移動がない。

基準座標と俣野法との関保を説明するために，拡散対の一 方の端例觉ばー $-\infty$ 飞距離座標軸 $x$ を固定し, $x$ 軸に垂直に 固定された多数の面から任意に選んだ図 1 の状態を想定す る. $\bar{V}_{1}=\bar{V}_{2}$ の関係を含めて式 $(8)$ が図 1 の面で成立すれば 俣野法が適用できる。な扮フィックの第 1 法則で与えられ た拡散流束が俣野法で求まる座標系を俣野の座標系と称する こともある，拡散による混合の結果，図 1 の二つの面の間 で構成物質の相関状態が变化し，物質の膨張あるいは収縮が 生じたとすれば，膨張収縮に応じて物質が面を通って外には み出るか中に入り込む. この状態は一般に $\bar{V}_{1}$ 抢よび $\bar{V}_{2}$ の それぞれが変数である場合に対応し， $x$ 軸が拡散対に固定さ

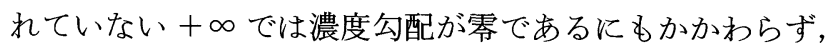
物質流束を作りだすので，俣野法が適用できない，俣野座標 系でないものに俣野法を適用すると，定義にしたがった正し

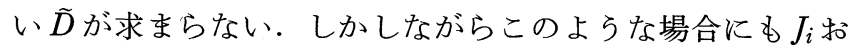
よび $F_{i}$ は存在し, これらの拡散流束の基準面は $x$ 軸上を移 動している.この種の移動は式 (7) 右辺第 2 項の $C_{i} u$ 形式 
で与兄られ，拡散とは直接関係のない物質流束であるので, $C_{i} u$ 項を排除するために種々に工夫し， $J_{i}$ あるいは $F_{i}$ さらに 相互拡散係数を無理なく求めることが可能である.

\section{4. カーケンドール効果とダーケン式}

\section{(1) カーケンドール効果 ${ }^{(10)}$}

マーカー移動現象としてのカーケンドール効果が発見され たのは1942年であり，1992年は発見の50周年であった。 カ ーケンドール効果については1947年の論文がよく引用され るので, 1942 1947の 5 年間は認知に必要な期間とい党る. カーケンドール効果の発見によって, 原子の種類に依存して 拡散の速さが異なるといら概念が始めて $\Sigma J_{i}=0$ の世界に導 入され，まさに画期的な発見であった。

\section{(2) ダーケンの解析 ${ }^{(11)}$}

図 1 の体積要素の中で空孔が発生あるいは消隇すれば, それ応じて格子点が発生あるいは消隇する。このような場 合には, 混合に上る体積変化と同様に $C_{i} u$ 項が発生し, 俣野 法の適用が不可能となる.ダーケンは相互拡散に特ける空孔 の持つ意味を十分認識しながら空孔を無視し，カーケンドー 几効果を解析した。解析の原点は基準座標にあり, 固定され た俣野座標系に対して移動するマーカー固定の座標系を設定 し, 両者の拡散流束の関係を次式で表した.

$$
-\tilde{D} \frac{\partial C_{i}}{\partial x}=-D_{i} \frac{\partial C_{i}}{\partial x}+C_{i} v
$$

ここに $D_{i}$ は成分 $i$ の固有拡散係数である. 前章の混合に上 る密度変化に対応する式 $(7)$ では， $\widetilde{D}$ はとのままで濃度勾 配項が変化しているに対して, 式 (9)では濃度勾配が同じ で拡散係数が変化している.ダーケンに上れば式 $(9)$ の $C_{i} v$ は川の流れに相当し, 原子一つ一つの移動ではなく, gross flow（原子集団としてのまとまった流れ）である。 $\widetilde{D} は C_{i} v$ を 包含し, $\left[D_{i}+C_{i} v\left(\partial x / \partial C_{i}\right)\right]$ ゲ党らる, $\widetilde{D}$ と $D_{i}$ との関係に は, 使用する俣野座標系の種類に依存して, 下記の 3 種類 の形式がある.

体積固定座標系 $\tilde{D}=C_{1} \bar{V}_{1} D_{2}+C_{2} \bar{V}_{2} D_{1}$

モル数固定座標系 $\tilde{D}=N_{1} D_{2}^{\prime}+N_{2} D_{1}^{\prime}$

質量固定座標系 $\widetilde{D}=W_{1} D_{2}^{\prime \prime}+W_{2} D_{1}^{\prime \prime}$ ここに $C_{i} \bar{V}_{i}$ は体積分率， $W_{i}$ は質量分率であり，空孔は全く 考慮されていない，俣野座標系と移動する座標系との関係か ら式(10)〜(12)を得るための計算方法の一例として, 最も 上く用いられるモル数固定座標系について説明する.

$$
-\frac{\tilde{D}}{V} \frac{\partial N_{i}}{\partial x}=-\frac{D_{i}^{\prime}}{V} \frac{\partial N_{i}}{\partial x}+\frac{N_{i}}{V} v^{\prime}
$$

式(13)の左辺は式 ( 7 )の右辺第 1 項と同じモル数固定座標 系の相互拡散流束 $F_{i}$, 左辺第 1 項はモル数基準で表した固 有拡散流束打よび第 2 項は gross flow である. $i$ が 1 と 2 の 二つの式(13)の和を求め整理すると, $\Sigma F_{i}=0$ であるから,
次式が成立する.

$$
-\frac{1}{V} v^{\prime}=-\frac{D_{1}^{\prime}}{V} \frac{\partial N_{1}}{\partial x}-\frac{D_{2}^{\prime}}{V} \frac{\partial N_{2}}{\partial x}
$$

式(14)を式(13) 飞代入し, 式(11)を得る. もちろん, $V か ゙$ 一定であれば式(10)と(11)は等しく, さらに成分 1 と 2 の 原子量が同じであれば式(12)を含めた三つの式は等価にな る.

式(11) そ和いて $N_{2} \rightarrow 0$ の局限では $\widetilde{D}=D_{2}^{\prime}$ であり, 同時に 式(13) から $\tilde{D}=\left[D_{1}^{\prime}+N_{1} v^{\prime}\left(\partial x / \partial N_{1}\right)\right]$ である. 多くの実験結 果から, 成分 2 の濃度零への $\widetilde{D}$ の外挿值は成分 1 中の成分 2 の不純物拡散係数に等しい.さらに, 成分 2 の不純物拡散 係数は $N_{2} \rightarrow 0$ に抢ける $D_{2}^{\prime}$ と等価とみてよいから， $N_{2} \rightarrow 0$ の 極限で $\widetilde{D}$ が $D_{2}^{\prime}$ 飞等しいことはダーケンの解析の正しいこと を示す。

$V$ が定数であれば $D_{i}^{\prime}=D_{i}$ であり, 固有拡散係数 $D_{i}$ と自 己拡散係数 $D_{i}^{*}$ との関係をダーケンは式(15)で与えた.

$$
D_{i}=D_{i}^{*}\left(1+\frac{\mathrm{d} \ln \gamma_{i}}{\mathrm{~d} \ln N_{i}}\right)
$$

ここに $\gamma_{i}$ は成分 $i$ の活量係数である. 式(15)には濃度 $N_{i}$ が 含まれるので, 完全には濃度勾配とは無関係ではないが, 原 子を特定の方向核かそらとする熱力学的な力は固有拡散俰 数に包含され，さらに式(10)から(12)を経て $\widetilde{D}$ 亿包含され る.ダーケンはカーケンドール効果を生じるような拡散の機 構について質問を受けながら, 決してそれに答えることはな かった。 その理由の一つは前に述べた空孔関連であり, 他は 俣野座標系に gross flow が存在することでフィックの法則 が成り立たず，一定濃度では相互拡散係数が定数であると の命題が崩れる可能性が生じたためと考兄られている. Guiraldenq ${ }^{(12)}$ は自己拡散に比較して, 相互拡散はフィック の法則についての極めて粗い近似と述べている.

\section{(3) 空孔流}

気体抢よび液体内の相互拡散では, ケミカルポテンシャル の勾配が物質の動きに影響を与えても, 直ちに逆向きの物質 移動が生じて，物質の個々の動きから $\Sigma J_{i}=0$ を満足する。 ただし拡散の行程を妨害するかたちで，半透膜の上らなるの を挿入すれば, 膜そのものがマーカーの役割をするにして も，膜から離れると $\Sigma J_{i}=0$ である。

結晶化した固体では, カーケンドール効果が生じれば, カ ーケンドールマーカーの一方の側で格子点が増加し, 他の側 で格子点が減少しなければならない。このためには一方で空 孔が発生し, 他方で消失する形式で空孔流を作る.カーケン ドール効果の出現は拡散の空孔機構説の論拠となり, 2 元系 相互拡散現象を空孔を含めた 3 元系として取り扱ら道が開 けた。しかしながら，空孔流の存在は系が非平衡状態にある ことを示すので, 平衡への緩和過程の特徵としてケミカルポ テンシャルの勾配の存在を考慮する必要があった。原子に対 する駆動力としケミカルポテンシャルの勾配を用い, 空孔を 
成分とした 1-2-Vの 3 成分系の拡散流束は下式で表される.

$$
\begin{aligned}
& j_{1}=-L_{11} \frac{\mathrm{d} \mu_{1}}{\mathrm{~d} x}-L_{12} \frac{\mathrm{d} \mu_{2}}{\mathrm{~d} x}-L_{1 \mathrm{v}} \frac{\mathrm{d} \mu_{\mathrm{v}}}{\mathrm{d} x} \\
& j_{2}=-L_{21} \frac{\mathrm{d} \mu_{1}}{\mathrm{~d} x}-L_{22} \frac{\mathrm{d} \mu_{2}}{\mathrm{~d} x}-L_{2 \mathrm{v}} \frac{\mathrm{d} \mu_{\mathrm{v}}}{\mathrm{d} x} \\
& j_{\mathrm{v}}=-L_{\mathrm{v} 1} \frac{\mathrm{d} \mu_{1}}{\mathrm{~d} x}-L_{\mathrm{v} 2} \frac{\mathrm{d} \mu_{2}}{\mathrm{~d} x}-L_{\mathrm{vv}} \frac{\mathrm{d} \mu_{\mathrm{v}}}{\mathrm{d} x}
\end{aligned}
$$

ここに式(16) (18)の左辺 $j_{i}$ は格子面基準(Lattice system) (13)で, 固有拡散流束とみなされている. 空孔が発生 あるいは消滅する位置では $j_{i}$ が不連続になるので, 格子面 基準では空孔が発生あるいは消隇せず，格子点が保存される ことを前提として，式(19)を利用する．な敃空孔流 $j_{\mathrm{v}}$ の代 わり

$$
j_{1}+j_{2}+j_{\mathrm{v}}=0
$$

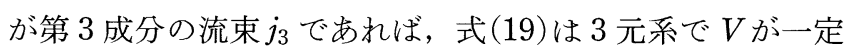
の場合あるいはモル数固定座標系に掓る拡散流束の定義式 となる.

式(19)を変形すれば次式となる.

$$
j_{1}+j_{2}=-j_{\mathrm{v}}
$$

前項までのダーケンの解析では, 空孔の存在を無視し式 (14)を誘導したので, 式(20)

$$
j_{1}+j_{2}=-\frac{1}{V} v^{\prime}
$$

の代わりに式(21)を使用したことになる。したがって， $j_{\mathrm{v}}$ $=(1 / V) v^{\prime}$ で, $(1 / V)$ は単位体積当たりの合金の量として保 存量である. この意味から, マーカーが固定されている格子 面では格子点が保存されなければならないので, ダーケンの 解析が格子面基準座標の着眼点となった。また，ダーケンは 式(15)を誘導するに際し，空孔を考慮しない立場から式 （16）を簡略化し，近似として式(22)を使用した.

$$
j_{i} \equiv-D_{i} \frac{\mathrm{d} C_{i}}{\mathrm{~d} x}=-L_{i i} \frac{\mathrm{d} \mu_{i}}{\mathrm{~d} x}
$$

現実の拡散で生じるカーケンドール効果は空孔が非保存で あるために生じる現象であるから, 非保存現象に取り組む研 究(14) はあるものの, 数式として取り扱らことは極めて困難 であり，また完全には成功していない。

\section{5. 反応拡散と界面反応}

前章までは単一相内の拡散について述べた。拡散に 2 相 以上の相が関与し, 異相界面が移動する過程を含も拡散現象 を反応拡散と称する. 界面で相接する 2 相の結晶構造が異 なるのが普通であるが，例光ば $\mathrm{Cu}-\mathrm{Ag}$ 系の上らに， $\mathrm{Cu}(\alpha)$ および $\mathrm{Ag}(\alpha)$ はいずれも $\mathrm{fcc}$ 構造であるにもかかわらず, 両者の間に濃度ギャップが存在するので, 異種相として取り 扱われる。 また 1 次固溶体以外飞中間相が新たに発生する よらな例では, 新相は核形成過程を経て成長する。新相発生 過程が存在しても, 異相界面移動を伴えば反応拡散と称さ
れ，ときには多相拡散とも言う。反応拡散の実験で，マルチ プルマーカー拉よびカーケンドールマーカーを使用すれば, 移動する異相界面で生じる界面反応沉かかわる原子の動きを 知ることが可能となる.な拉マーカーについては後で一括し て説明する.

筆者等が試みた $\mathrm{Cu}-\mathrm{Zn}$ 系 $\alpha-\beta$ 拡散対 ${ }^{(15)}, \mathrm{Pt}-\mathrm{Au}^{(16)}$ 抒よび $\mathrm{Cu}-\mathrm{Ag}^{(17)}$ 拡散対内の反応拡散実験で，これらの系に共通し た現象をわかりやすく不偏的に説明するために，架空の AB 2 元系包晶型平衡状態図を図 3 亿示す。 まず純成分 $\mathrm{A}$ と Bのそれぞれから成る拡散対を作成し，温度 $T_{1}$ で加熱す る。得られた濃度 $\left(C_{\mathrm{A}}\right)$-距離 $(x)$ 曲線を図 4 亿示す。図の M. i. 抢よびK. i. は俣野面とカーケンドールマーカー界面で あり, 俣野面に対して左側に $\alpha / \beta$ 界面, 右側飞K. i. が存在 する. もちろん， $t=0$ では 3 種類の面は一致して俣野面位

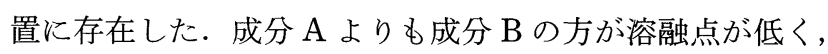
$D_{\mathrm{B}}>D_{\mathrm{A}}$ であることに起因し，K. i. は右に移動している.

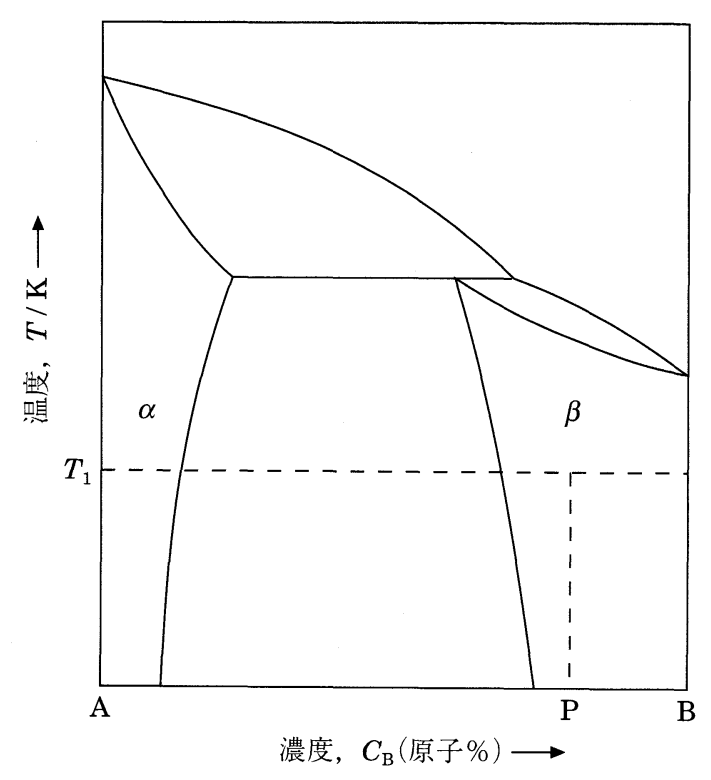

図 3 A-B 2 元系平衡状態図.

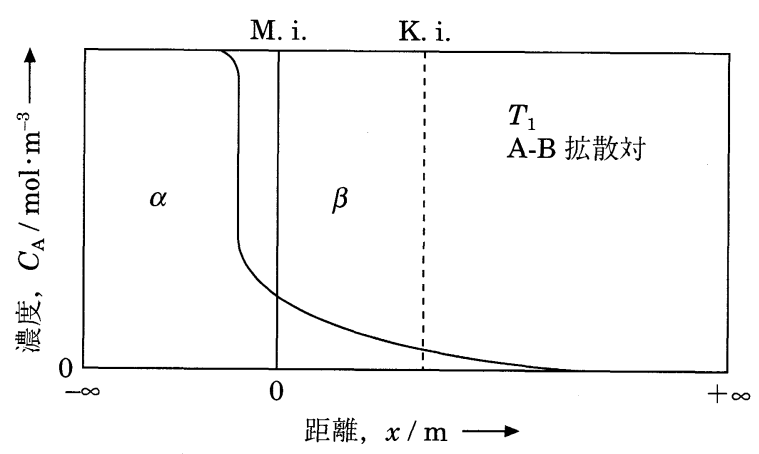

圀 4 A-B 拡散対内の $C_{\mathrm{A}}-x$ 曲線. 界面反応の存在に上 って異相界面(i. i.) と K. i. とが一致しない.（定 性図） 
これに対して $\alpha / \beta$ 界面は左側へ移動しているので， $\alpha / \beta$ 界 面の移動と K. i. のそれとはメカニズムが異なると考えてよ い.

カーケンドールマーカーは加熱時間 $t=0$ で拡散対の接合 面に挿入されたマーカーを意味する．単に拡散対の接合面だ けではなく, 拡散対内のすべての領域に存在するマーカーを 総称したものがマルチプルマーカーである. カーケンドール 効果の発見以来, マーカー移動現象は拡散の進行によって空 孔(格子点)の発生による膨張あるいはそれらの消滅による収 縮を示すものと考号れているので，マルチプルマーカーを 用いれば，拡散対内のいかなる位置で膨縮が生じるかが明ら かになる。そこで図 4 に示した $C_{\mathrm{A}}-x$ 曲線が得られるよらな 拡散対内のマルチプルマーカー配列の変化を図 5 に示す。斜 破直線 DEF は加熱前の純 A の領域に埋没されたマルチプル マーカー配列であり, この斜破直線からの逸脱部分の $\mathrm{EGH}$ が加熱によるマーカー移動を示す. 加熱前は純 A であった 領域で, $\mathrm{E}$ 点から異相界面 (interphase interface, i. i. と略 す)の間で膨張が生じたことを曲線 EG が示している. カー ケンドールマーカーは Mi から Ki をで移動するので, F 点 が H 点まで移動したことになる. i. i. は空孔を作りながら 純 $\mathrm{A}$ 側に移動する結果, i. i. 上の $\mathrm{G}$ 点で折れ曲がり, $\mathrm{G}$ 点 での屈曲の程度が大きい汪ど空孔の発生量が大である(15) (16).

純 A から K. i. に至るまでの拡散領域で空孔が発生し，その 領域が膨張したことに伴い，K. i. から純 B までの拡散領域 では空孔が消失し, 膨張を打ち消すかたちで収縮が生じるべ きである。しかし純 B 部分にマルチプルマーカーを挿入す ることが難しく, 実験を行っていないので, 収縮側のマーカ 一移動については明らかでない。

つぎに $\alpha / \beta$ 界面移動を詳しく調べるために，拡散対の一 方の純 $\mathrm{A}$ はそのままで, 他方の拡散しやすい成分 $\mathrm{B}$ の部分 に成分 $\mathrm{A}$ を添加した合金を使用する。合金中 A の濃度が増 加するにしたがって $\alpha / \beta$ 界面と K. i. との間の距離が短くな

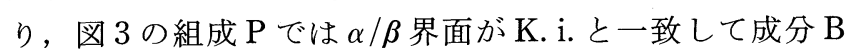
の濃度の多い注らに向かって移動した。 $\alpha / \beta$ 界面と K. i. と が一致した場合の $C_{\mathrm{A}}-x$ 曲線を図 6 に示す. 図 4 では $\alpha$ 相内

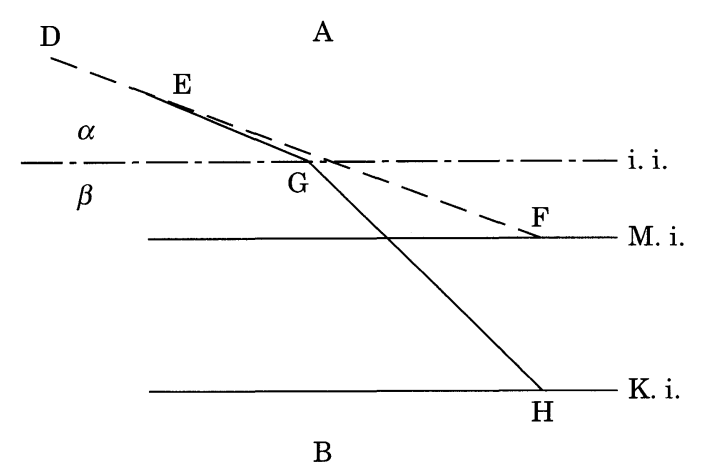

図 $5 \mathrm{~A}-\mathrm{B}$ 拡散対内 $C_{\mathrm{A}}-x$ 曲線に対応したマルチプルマ 一カ一配列の変化.（定性図）

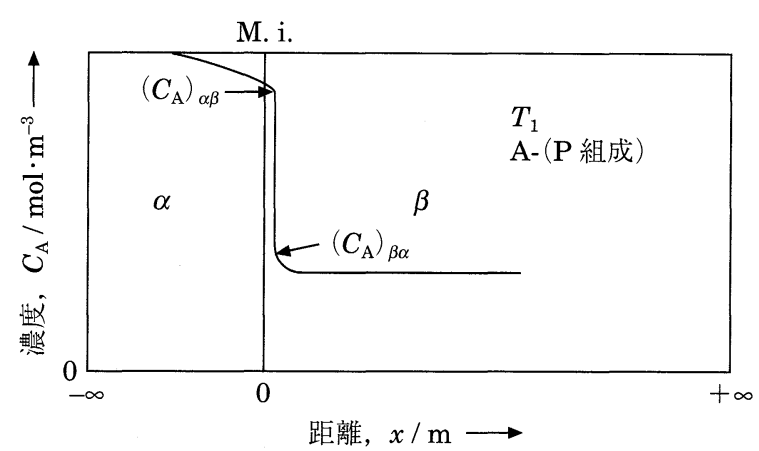

図 $6 \mathrm{~A}-\left(\mathrm{P}\right.$ 組成) 拡散対内の $C_{\mathrm{A}}-x$ 曲線, i. i. と K. i. と が一致する.（定性図）

の界面付近の濃度勾配が特に大きいので, $\left(C_{\mathrm{A}}\right)_{\alpha \beta}$ は平衡状 態図記載の值に近いと言える程度で，実験上の值はよくわか らない。他方 $\left(C_{\mathrm{A}}\right)_{\beta \alpha}$ は図 4 と図 6 では異なり, $\left(C_{\mathrm{A}}\right)_{\beta \alpha}$ が図 4 では数\%平衡濃度よりも低く, 図 6 では平衡濃度に注淁一 致することがわかった。 ここでの成分 $\mathrm{A}$ は $\mathrm{Cu}-\mathrm{Zn}, \mathrm{Pt}-\mathrm{Au}$ 拉 よび $\mathrm{Cu}-\mathrm{Ag}$ の各系の $\mathrm{Cu}, \mathrm{Pt}$ および $\mathrm{Cu}$ に対応する. 図 6 の 濃度一距離曲線が得られる拡散対内のマルチプルマーカー配 列の変化は単調であり, 純 $\mathrm{A}$ 部分に挿入されたマルチプル マーカーは, K.i. に至るまでの $\alpha$ 拡散領域で, 図 5 の曲線 EGのように下方に向かって少し湾曲しただけである.な拉 マルチプルマーカーは通常拡散方向に対して $(\pi / 4) \operatorname{rad} の$ 角 度で埋没(18)されている.この角度にこだわる必要はないが， 固有拡散係数を求めるための定量的実験では角度を正確に定 めなければならない，単に膨張収縮の位置を知るための定性 実験では，マルチプルマーカー配列の角度の正確性について 特に配慮する必要はない。

反応拡散については，1950年代に俣野座標系の拡散流 束, $J_{i} \equiv-\widetilde{D}\left(\partial C_{i} / \partial X\right)$ と界面移動速度 $\omega$ との関係を表す式 (23) が提出された ${ }^{(19)}$.

$$
\left(J_{i}\right)_{\alpha \beta}-\left(J_{i}\right)_{\beta \alpha}=\left[\left(C_{i}\right)_{\alpha \beta}-\left(C_{i}\right)_{\beta \alpha}\right] \omega .
$$

当初は, 相接する $\alpha / \beta$ 界面で平衡が成立し, 2 相の界面濃度 が平衡状態図にしたがって一定といら条件が付与されてい た。しかしながら現在では, 必ずしも平衡状態図の界面濃度 でなくても, 界面で局所平衡が成立し, 界面濃度が一定であ ればよいといら程度に条件を緩めているようである。 $\alpha / \beta$ 界 面で局所平衡が成立したとすれば， $C_{i}-x$ 曲線は不連続である としても，ケミカルポテンシャル $\left(\mu_{i}\right)-x$ 曲線は連続する ${ }^{(20)}$. 前章の空孔を考慮した式 $(16) \sim(18)$ では， $\mu_{i}$ が連続で $x$ による微分が可能となっている. これらの式で定義される固 有拡散流束について成分 $i$ が保存されていれば式(19)が成立 する，異相界面で空孔が発生あるいは消隇しなければ，互い に接する $\alpha$ 格子面和よび $\beta$ 格子面は保存され，これらの格 子面はマーカーを固定する資格を持つ. そこで，マーカー移 動速度 $v$ と異相界面移動速度 $\omega$ を等しく置いて, マーカー の代わりに $\alpha / \beta$ 界面について式 (9)を書き換える. 


$$
\begin{aligned}
& \left(J_{i}\right)_{\alpha \beta}=\left(j_{i}\right)_{\alpha \beta}+\left(C_{i}\right)_{\alpha \beta} \omega \\
& \left(J_{i}\right)_{\beta \alpha}=\left(j_{i}\right)_{\beta \alpha}+\left(C_{i}\right)_{\beta \alpha} \omega
\end{aligned}
$$

$\left(j_{i}\right)_{\alpha \beta}=\left(j_{i}\right)_{\beta \alpha}$ を考慮し, 式 $(24)$ から式(25)を差し引けば式 (23) が得られる. $j_{i}=-D_{i} \partial C_{i} / \partial x$ であるから, 異相界面で局 所平衡が成り立ち, 図6 の上らに異相界面とK. i. とが一致 し，カーケンドール効果によって移動する場合には， $\left(D_{i}\right)_{\alpha \beta} /\left(D_{i}\right)_{\beta \alpha}=\left(\partial C_{i} / \partial x\right)_{\beta \alpha} /\left(\partial C_{i} / \partial x\right)_{\alpha \beta}$ の関係が得られる.

局所平衡が成立しない界面では， $\mu_{i}$ が不連続であり，こ れが駆動力となって界面反応が生じる。例光ば図 4 のよう そ, $\beta$ 相が $\alpha$ 相を食べて成長寸る際の界面反応は界面での相 変態に関与する atom shift ${ }^{(15)}$ 拉よび空孔の発生から成る. 換言すれば，界面で $\alpha$ 相の格子面が $\beta$ 相に取り込まれ相変 態に生じる際，空孔が湧出することになるが， atom shiftは 成分 $\mathrm{A}$ 打よび $\mathrm{B}$ の両原子が $\alpha$ 相から離孔て $\beta$ 相に移ること を意味するので， $\alpha$ 相の $\beta$ 相への溶解と表現してもよい. 図 4 亿打碑相界面の移動にはカーケンドール効果もわずか に影響しているが，汪とんどは atom shift による．界面で の局所平衡については, “平衡に達するには注んの数オング ストローム程度の拡散が起こればよいのに対し，界面領域か らその成分を取り去るにはずっと長い距離の拡散が必要であ るので, 界面での平衡の仮定は成り立つことが多い”(20) と考 兄られてきた. 局所平衡から離れ, 系の速やかな緩和に寄与 するよらな非平衡から生じる界面反応着目し，拡散速度の 遅い $\mathrm{A}$ 原子が拡散に頼らず atom shift により $\alpha$ 相から $\beta$ 相 へ移行し, 発生した空孔が拡散速度の速い $\mathrm{B}$ 原子の移動に 寄与寸ると考えたほうが確かなようである。

図 4 扣よび 6 で俣野面を書き加える際には，俣野法適用 の可否を確認するため，これらの図が求まる条件で加熱時間 を変光，それぞれ別個に $C_{i}$-ボルッマン变数 $(\lambda)$ 曲線を描く 必要がある。それによって，少なくとも実験を行った条件下 で $\widetilde{D}$ 拈よび $D_{i}$ がそれぞれ一定濃度に扑いて定数であること も確認される. 図 4 と図 6 とでは異相界面の移動方向招よ び移動機構は異なるものの, 成長する相の格子点数が増加 し，縮退する相内で増加分相当の格子点数が減少すると考兄 て, 俣野法を適用しているので, 界面基準の物質流束は界面 で連続しなければならない，そこで新しく界面固定座標系を 考光, その座標系の拡散流束, $j_{i}^{\prime} \equiv-\delta_{i} \partial C_{i} / \partial x$, 之俣野座標 系の拡散流束 $J_{i}$ との関係を式 $(24)$ 拉よび $(25)$ の $j_{i}$ を $j_{i}^{\prime}$ 亿置 き換光ることで表すことができる. $\left(j_{i}^{\prime}\right)_{\alpha \beta}=\left(j_{i}^{\prime}\right)_{\beta \alpha}$ であるか ら, 前と同様に式(23)が誘導され, 式(26)が求まる.

$$
\widetilde{D}=N_{1} \delta_{2}+N_{2} \delta_{1}
$$

図 7 は図 4 の $C_{\mathrm{A}}-x$ 曲線についての $J_{\mathrm{A}}$ 抢よび $j_{\mathrm{A}}^{\prime}$ と $x$ との

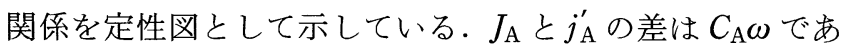
る. $J_{\mathrm{A}}$ は異相界面で不連続であり, $x= \pm \infty$ で零となる。 こ れに対して $j_{\mathrm{A}}^{\prime}$ は界面で連続し, $+\infty$ で $C_{\mathrm{A}}=0$ で $C_{\mathrm{A}} \omega=0$ となるけれども， $-\infty$ では $C_{\mathrm{A}} \neq 0$ とよる $C_{\mathrm{A}} \omega \neq 0$ 亿起因し て， $j_{\mathrm{A}}^{\prime}$ は零にはならない。一般に異相界面が俣野座標系に 対して移動するような場合には, $\widetilde{D} は\left(\delta_{i}+C_{i} \omega \partial x / \partial C_{i}\right)$ であ

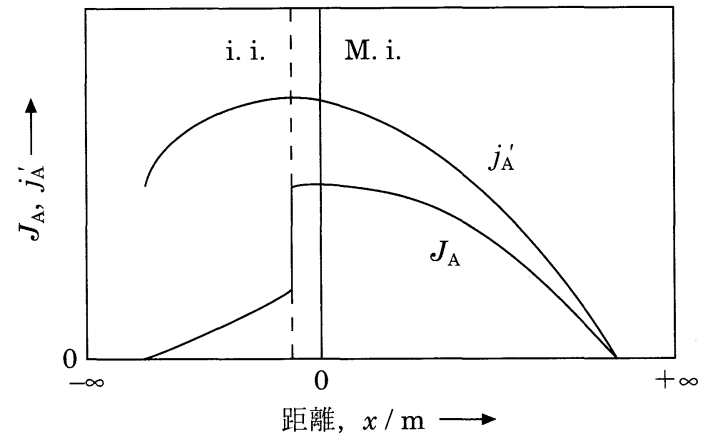

図 $7 \quad J_{i}$ と $j_{i}^{\prime}$ との関係. (定性図)

り，フィックの法則からは逸脱しても，空孔を無視すること で $\Sigma J_{i}=0$ を成立させている. $j_{i}^{\prime}$ は atom shift を包含し，乙 かも atom shift の程度は実験条件飞依存するので， $j_{i}^{\prime}$ は拡 散流束ではなく， $\delta_{i}$ は拡散係数でもない，属する座標系の相 違から, atom shift の生じているような異相界面では固有拡 散係数は存在しない。

van Loo ら ${ }^{(21)}$ はコンピュータによる数值解析法で反応拡 散現象を解明することを試みた。成分 A 拈よび B の合計を 一定の数に区切る面を俣野面，扣上び俣野座標系を $N$ 座標 系とし, 従来ど括り $\Sigma J_{i}=0$ と执いた。異相界面の移動は $N$ の変化速度によって与兄られ, 固有拡散流束については式 （19）を用いて空孔を保存させ，空孔流を含めて $\Sigma j_{i}=0$ とお いた，さらに界面反応として，異相界面に淤る空孔の発生 あるいは消失現象を界面に打ける固有拡散流束の不連続性に むすびつけた。本稿で述べたような atom shift は考慮され ていないが, 2 元系の $\Sigma J_{i}=0$ と空孔を含む 3 元系の $\Sigma j_{i}=0$ を同時に数式化することで，ダーケンの解析では考慮されて いない空孔を新た汇導入した結果，今までに予想もできなか ったマーカーの動きが描きだされ，興味ある結果を誘導して いる。

\section{6. おわりに}

2 成分系の相互拡散実験を多くの系で試み，俣野法で $\tilde{D}$

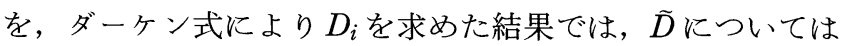
特別な例を除いて混合による体積変化を考慮する必要がなか ったが， $D_{i}$ については体積变化を補正する必要があった。 $\widetilde{D}$ を求めるに際し，例觉ば俣野面の位置が少々異なっても 影響は少なく， $D_{i}$ には大きな影響がある。 $\widetilde{D}$ が鈍感である のは, フィックの法則からの逸脱現象が拡散対内に生じて も, 図 1 亿扣ける $J_{i}$ 亿匡とんど影響がないからであろら。 またカーケンドール効果はフィックの法則からの逸脱現象で あり，逸脱の程度を表す $D_{i}$ 亿は実験条件が影響するものと 考光られる。しかしながら，マーカー固定面では格子点が保 存されていて，乙か子拡散対全体として式(19)が近似的に 成立していれば， $D_{i}$ は物性值としての意味を持つものと考 
えられる。

反応拡散の初期には，相接する $\alpha$ 护よび $\beta$ 両相間の成分 $i$ についてのケミカルポテンシャルの相違は界面に集中するの で，一方の相が他方に溶解する形で界面反応が進行する. $\alpha$ 相が $\beta$ 相に溶解するとすれば，溶解物質の $\beta$ 相中での拡散 によって界面反応が律速される. やがて $\alpha$ 相内の界面近傍 飞子拡散生成層が形成され, 界面反応は拡散生成層内の拡散 によって律速される。このあたりまでの界面移動は主として atom shift に上る. 次いで界面反応が消失し， $\alpha / \beta$ 界面で局 所平衡が成立する. 局所平衡は見かけ上の平衡であり, 最終 の熱力学的平衡状態に到達するには, 再び界面反応が関与し て拡散対全体が $\alpha$ または $\beta$ の単一層となるか，あるいは $\alpha /$ $\beta$ 界面で接する 2 相共存になるかである。この状況は拡散対 を構成する $\alpha$ 試料扮よび $\beta$ 試料それぞれの大きさと平衡状 態図との関係から定まる. 本稿の図 4 と 6 との関係を含め て最終平衡に向から過程での $\alpha / \beta$ 界面の移動の方向は一定

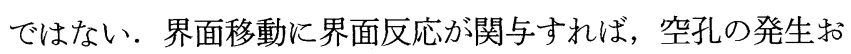
よび消滅, これに伴う空孔流, さらには異相界面に淤ける相 変態にかかわる atom shift などフィックの法則とは直接関 係の無い現象が界面に集中して生じる。フィックの法則から 逸脱の程度が大きくなり，それが実験方法に依存すれば， $\tilde{D}$ 飞も影響が現れる。

界面反応の結果, 界面で原子が再配列するに際し, 再配列 部分と拡散対内に始めから存在する部分との間に原子配列の 整合性があり，再配列部分がェピタキシーとなる可能性があ る. 再配列部分に拡散異方性があれば，拡散係数は実験方法 に依存する。このような新しい問題以外飞, 我々が既存の方 法あるいは理論を用いて反応拡散現象を解明しょうとすると き, 例艺ば俣野法ではボルッマン变数の導入の可否について の確認は必ず必要である。既存の方法抢よび理論には条件あ るいは仮定が付随していることが多く，これを知るには原典 が最良であるのは当然として, 初学者の場合には拡散につい
ての研究の流れをたどりながら原典の趣旨を優れた教科書で 理解するのも一つの方法である. 以下に文献として原典とと もに，教科書での記載頁を示した。

\section{文献}

（1） P. G. Shewmon 原著, 笛木和雄, 北沢宏一共訳 : 固体内の拡 散, コロナ社, (1976), 45.

（2） P. G. Shewmon 原著, 笛木和雄, 北沢宏一共訳 : 固体内の拡 散, コロナ社, (1976), 2.

( 3 ) J. Grank: The Mathematics of Diffusion, Oxford University Press, (1967), 223.

(4) K. Compaan and Y. Haven: Trans. Faraday Soc., 52(1958), 786 ; 文献 $(1), 111$.

( 5 ) J. G. Mullen: Phys. Rev., 121(1961), 1649.

(6) C. Matano: Japan. J. Phys., 8(1933), 8 ; 文献(1), 31.

(7) R. R. Hasiguti: Defect and Diffusion Forum, 95-98 (1993), 3.

（8）大西正已, 下㠃敏唯: 日本金属学会誌, 46(1982), 1.

(9) M. Onishi, Y. Wakamatsu, T. Shimozaki: Trans. JIM., 25 (1984), 11.

(10) A. Smigelskas and E. Kirkendall: Trans AIME, 171(1947), 130 ; 文献 $(1), 130$.

(11) L. Darken: Trans. AIME, 174(1948), 184 ; 文献(1), 131.

(12) P. Guiraldenq 著, 平野賢一・岡田 健訳 : 技術者の拡散入 門, 共立出版, (1984), 41.

(13) P. Shewmon: Diffusion in Solids, 2nd. Ed. TMS, (1989), 134.

(14) J. S. Kirkaldy: Scripta Met., 21 (1987), 33.

(15) M. Onishi, K. Kuwayama and Y. Murata: Trans. JIM, 31(1990), 1028.

（16）桑山健太, 若松良徳, 下㠃敏唯, 大西正已 : 日本金属学会誌, $\mathbf{5 5}$ (1991), 515.

(17) 大西正已：投稿準備中.

(18) Y. Iijima, K. Hirano and M. Kikuchi: Trans. JIM, 23(1982), 19.

(19) W. Seitz: Diffusion in Metallen. 2 Aufl., Springer Verlag, Berlin, (1955), 157; P. Shewmon: Diffusion in Solids, 2nd. Ed. TMS, (1989), 39.

（20） P. G. Shewmon 原著, 笛木和雄, 北沢宏一共訳 : 固体内の拡 散, コロナ社, (1976), 148.

(21) F. J. J. van Loo, B. Pieraggi and R. A. Rapp: Acta Metall Mater., 38(1990), 1769.

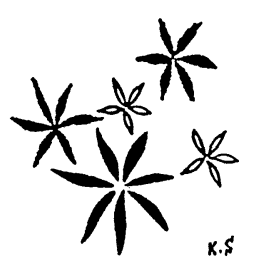

